\title{
Economic effects of promotion and relegation in parallel competitions
}

\author{
Thadeu Gasparetto* • Angel Barajas \\ National Research University Higher School of Economics, Russia
}

Received: 26 May 2021

Revised: 7 October 2021

Accepted: 14 October2021

\begin{abstract}
Previous research evidence some negative effects after league relegations. However, these works focused only on domestic league figures, overlooking that football clubs play in simultaneous tournaments. Therefore, the effects of relegation in a domestic league on those simultaneous championships remain unclear. Our dataset comprises twenty men's Brazilian State Championships from 2013 to 2017. Panel Data Ordinary Least Squares models are employed as econometric techniques. The results suggest that the promotions to the second tier of the Brazilian League increase both attendance and revenues of clubs while relegations impact them negatively. Nonetheless, the promotion to the top tier produces no significant increase, which may indicate a potential adverse demand effect. Further research may inspect whether it happens in European football.
\end{abstract}

Keywords: Attendance; Brazilian football; Professional football; Sports leagues; Simultaneous tournaments

JEL Classification Codes: L83, Z20, Z21, Z23, Z28

\section{Introduction}

Professional sports are considered as important economic elements in society nowadays. Associate football (or soccer in the United States), the most popular sport discipline worldwide, is often referred to as a business, industry or economic setting (Szymanski \& Smith, 1997; Kahn, 2000; Zimbalist, 2003). Therefore, unsurprisingly, most of the managerial features of football have been intensively investigated in the literature, such as change in management (Hughes, Hughes, Mellahi \& Guermat, 2010), customer satisfaction (Fernandes \& Neves, 2014) demand (Borland \& Macdonald, 2003), governance (Dimitropoulos \& Tsagkanos, 2012), human capital (Scafarto \& Dimitropoulos, 2018), information management (School \& Carlson, 2012), knowledge transfer (Trequattrini, Massaro, Lardo \& Cuozzo, 2019), labour market (Frick, 2007), marketing (Dionísio, Leal \& Moutinho, 2008), networks (Bond, Widdop \& Parnell, 2020), taxation and migration (Kleven, Landais \& Saez, 2013), among many others with clear economic and business implications.

\footnotetext{
*Corresponding author. E-mail: tgasparetto@hse.ru.

Citation: Gasparetto, T., and Barajas, A. (2022) Economic effects of promotion and relegation in parallel competitions, Economics and Business Letters, 11(1), 7-15.
}

DOI: 10.17811/ebl.11.1.2022.7-15 
Like other businesses, the structure of the sport industry has been extensively researched Noll (2003) and Szymanski (2003) provide detailed descriptions regarding the organization of sports leagues. The key feature of most of international football is its pyramidal structure. Football leagues are hierarchically organised: top clubs take part in the highest tiers and small (poorest) clubs regularly play at lower levels. The promotion and relegation system is the engine of this structure. Under this scheme, the worst-performing teams in top tiers are relegated to lower ones while the best clubs from lower tiers are promoted to the upper divisions. These movements of clubs among tiers cause different impacts on professional football clubs and the literature has been scrutinizing them over the last decades.

Negative effects on attendance are somehow expected after relegation. The relegation to a lower-tier implies many undesirable features. Beyond a likely disgraceful feeling for many supporters, clubs will naturally face a large decline in their revenues, most of the best players tend to leave the squads and some less attractive matches shall happen in the following season, due to the lower level of quality in playing. The combination of such elements, among others, may naturally reduce the supporters' willingness to attend matches.

The current research aims to inspect the effects of promotion and relegation through an original perspective. Previous research focused on match attendances in domestic leagues after a promotion or relation, but what happens to attendance on other simultaneous tournaments remains unclear and this study sheds light on it. For that, the Brazilian football market presents itself as an appropriate setting. That domestic football market has a distinctive characteristic compared to other domestic ones worldwide: the market is primarily organised at state levels by the State Federations. In order to take part in any national competition, football clubs must be associated with a State Federation and, consequently, play at State Championships every season. In addition, these State Championships are used as a qualifying tool to the lowest tier of the Brazilian League (fourth tier - Serie D) as well as to the Brazilian Cup. Therefore, this work inspects whether promotions and relegations at national levels impact the consumption of men's football at state level championships for the first time. Our empirical results may offer valuable insights to State Federations, since they organise State Champioships and directly benefit from higher attendance rates and matchday revenues. At the same time, football clubs, television channels and sponsors would also be concerned whether promotions and relegations increase or decrease the general interest in football tournaments.

\section{Theoretical background}

Solberg and Haugen (2010) claim that the organization of European football creates a cost-push effect once clubs constantly increase expenses to achieve promotion, avoid relegation and classify to international competitions. As a consequence, such mechanism makes clubs spend more than they can afford. Many papers corroborate with these assumptions, showing that clubs are regularly facing insolvency risks in England (Beech, Horsman \& Magraw, 2010; Szymanski, 2017), France (Scelles, Szymanski \& Dermit-Richard, 2018), Germany (Szymanski \& Weimar, 2019) and Spain (Barajas \& Rodríguez, 2010; Barajas \& Rodríguez, 2014), for example.

Noll (2002) earlier analysed the consequences of promotions and relegations in English football. Among his main findings, it is highlighted that this structure leads to a net positive effect on attendances, where the boost on attendances is higher after promotions than the reductions from relegations. Scelles et al. (2013) also observed that recently promoted clubs have a significant positive impact on attendances-levels in the French football league. Buraimo, Simmons and Szymanski (2006) pointed out a large fall in attendances after relegations on English football, similarly to what Cerqua (2014) has found on Italian football as well as Scelles et al. (2018) in France. In addition, Scelles and François (2021) suggest that inferior average attendances in football leagues could be a consequence of the lower potential of the promoted clubs in attracting fans to the stadiums. 
The promotion and relegation system may also offer some externalities. Wallrafen, Pawlowski and Deustscher (2018) indicate a negative spillover effect on German football, where the overlap of matches of different tiers (first and fourth) generate an adverse demand effect for lower levels, reducing their demand for tickets. Pyun, Kim, Schlesinger and Matto (2020) offer a curious finding: the promotion of German clubs to the Bundesliga 1 positively impact local non-profit club memberships. The authors argue regarding potential benefits from that externality, such as the promotion of physical activity at a community-based level and, perhaps, a potential reduction in government spending on these activities.

The former pieces of evidence highlight variations in attendances during league matches. However, no previous work inspected what happens on attendance during simultaneous competitions. As explained above, the Brazilian football market constitutes an appropriate setting to analyse this. Besides league (4 tiers) and national cup, there are state championships, where clubs from $1^{\text {st }}, 2^{\text {nd }}, 3^{\text {rd }}, 4^{\text {th }}$ and non-division clubs play among them for a professional regional title every season. Therefore, this work tries to understand the impacts of promotions and relegations at a national league level on attendance and matchday revenues at state-level championships. Previous research on Brazilian football analysed the determinants of attendance in the top division of the men's Brazilian League (Madalozzo \& Villar, 2009; Gasparetto \& Barajas, 2020), in its all four tiers (Gasparetto, Barajas \& Rodríguez-Guerrero, 2020) as well as in some State Championships (Gasparetto, Barajas \& Fernandez-Jardón, 2018; Shakina, Gaparetto \& Barajas, 2020) but this question - whether a relegation in a national tournament impacts tickets consumption in a state-level championship - has not been addressed to the date.

\section{Method}

Panel Data Ordinary Least Squares (OLS) is employed to explain seasonal variations on average attendance (a) and average matchday revenues (r) on each championship $i$ and on each season $t$. The explanatory factors are dummy variables with value 1 for each specific condition: promotion from 2 nd tier to 1 st tier $(p 1)$; promotion from 3 rd tier to 2 nd tier $(p 2)$; promotion from 4th tier to 3rd tier $(p 3)$; relegation from 1st tier to 2 nd tier $(d 1)$; relegation from 2 nd tier to 3 rd tier $(d 2)$; and relegation from 3rd tier to 4th tier (d3). The dummies assume a value of 1 when promotion or relegation happened and 0 otherwise. State income per capita (in logarithm), number of clubs in each tier $i$ in season $t$ and the pool of clubs per state in all tiers in the previous season are used as control variables $(C V)$. The econometric models are presented below:

$$
\begin{gathered}
a_{i t}=\beta_{0}+\beta_{1} p 1_{i t-1}+\beta_{2} p 2_{i t-1}+\beta_{3} p 3_{i t-1}+\beta_{4} d 1_{i t-1}+\beta_{5} d 2_{i t-1}+\beta_{6} d 3_{i t-1} \\
+v C V_{i t}+\epsilon_{i} \\
r_{i t}=\delta_{0}+\delta_{1} p 1_{i t-1}+\delta_{2} p 2_{i t-1}+\delta_{3} p 3_{i t-1}+\delta_{4} d 1_{i t-1}+\delta_{5} d 2_{i t-1}+\delta_{6} d 3_{i t-1} \\
+\tau C V_{i t}+\varepsilon_{i}
\end{gathered}
$$

The dataset comprises twenty State Championships from 2013 to 2017 in which at least one club was promoted or relegated. Seven states are not included in the sample because they did not have any promotion and relegation over the researched period. Table 1 shows the total number of clubs promoted and relegated by state. Figures 1 and 2 show the differences in average attendance and matchday revenues by state.

\section{Results}

The outputs of the models are presented in Table 2. Breusch-Pagan test was carried out for checking heteroscedasticity and, indeed, it has been detected in both models 1 and 2. We first tried to fix it taken the dependent variables in logarithm form (ln) - as both attendance and matchday revenues shown a non-normal distribution. The results can be seen in models 3 and 4 . 
Table 1. Number of Clubs Promoted and Relegated by state (2013-17).

\begin{tabular}{lrrrrrr}
\hline \hline \multicolumn{1}{c}{ State } & P1 & P2 & P3 & D1 & D2 & D3 \\
\hline \hline Acre (AC) & 0 & 0 & 0 & 0 & 0 & 1 \\
Alagoas (AL) & 0 & 0 & 1 & 0 & 0 & 1 \\
Bahia (BA) & 1 & 0 & 0 & 1 & 0 & 0 \\
Ceará (CE) & 0 & 0 & 0 & 0 & 1 & 1 \\
Distrito Federal (DF) & 0 & 0 & 0 & 0 & 0 & 1 \\
Goiás (GO) & 1 & 1 & 1 & 1 & 1 & 1 \\
Maranhão (MA) & 0 & 1 & 1 & 0 & 1 & 0 \\
Minas Gerais (MG) & 1 & 0 & 1 & 1 & 0 & 0 \\
Mato Grosso (MT) & 0 & 1 & 0 & 0 & 0 & 0 \\
Pará (PA) & 0 & 1 & 0 & 0 & 0 & 0 \\
Paraíba (PB) & 0 & 0 & 2 & 0 & 0 & 2 \\
Pernambuco (PE) & 1 & 1 & 1 & 1 & 0 & 0 \\
Piauí (PI) & 0 & 0 & 1 & 0 & 0 & 1 \\
Paraná (PR) & 0 & 1 & 1 & 0 & 0 & 0 \\
Rio de Janeiro (RJ) & 0 & 2 & 1 & 1 & 1 & 2 \\
Rio Grande do Norte (RN) & 0 & 0 & 0 & 0 & 2 & 2 \\
Rio Grande do Sul (RS) & 0 & 2 & 2 & 1 & 0 & 0 \\
Santa Catarina (SC) & 2 & 0 & 0 & 1 & 1 & 0 \\
Sergipe (SE) & 0 & 0 & 1 & 0 & 0 & 0 \\
São Paulo (SP) & 1 & 0 & 1 & 1 & 2 & 3 \\
\hline \hline
\end{tabular}

Figure 1. Seasonal Average Attendance by State and Year

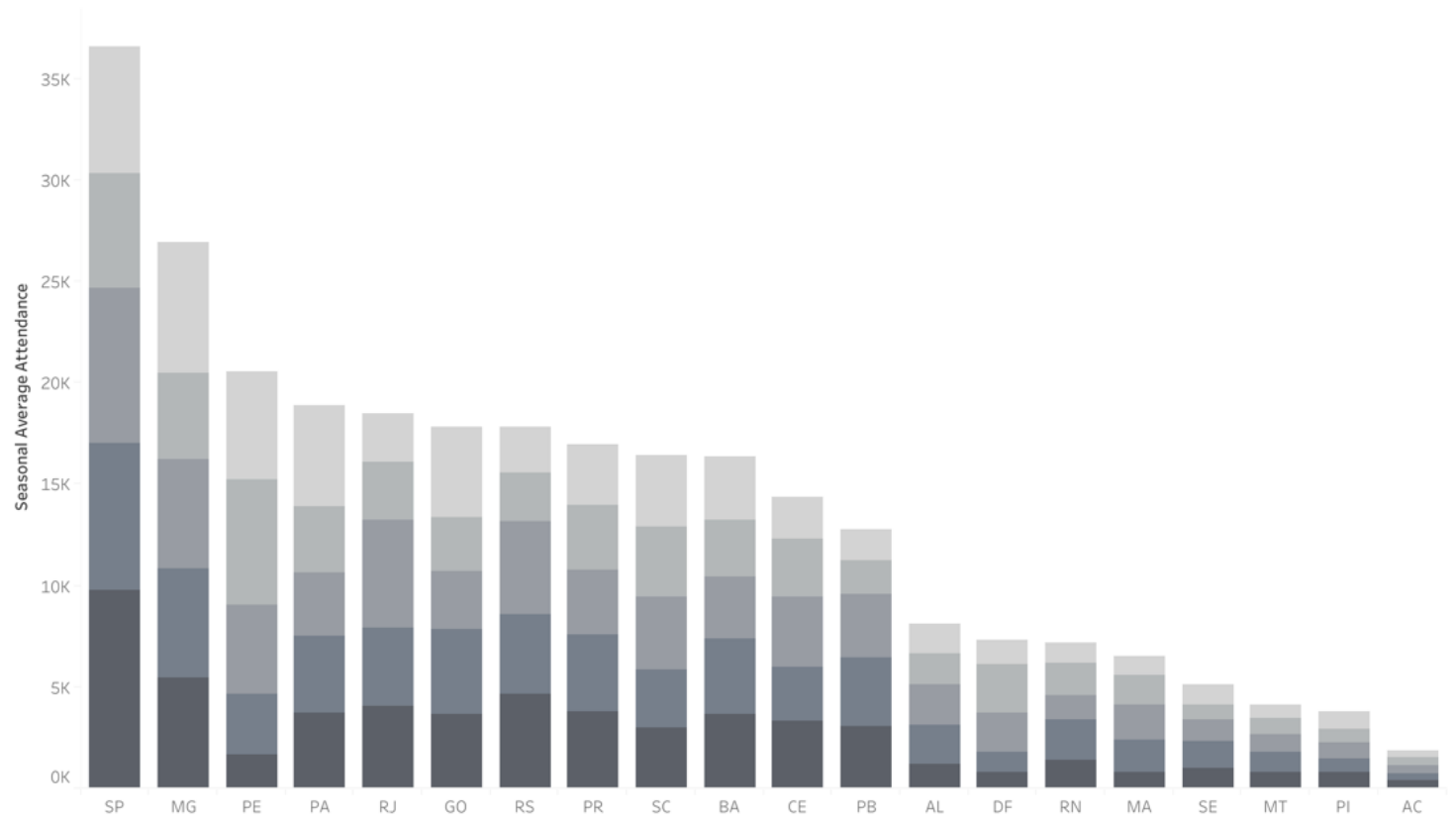

The heteroscedasticity has disappeared in the attendance model (3), but it persisted in the model for revenues (4). Hence, we applied robust standard errors - clustered by state- to correct this problem. Thus, Models 3 and 5 - highlighted in light grey - are used for interpreting the results.

The results show evidence that the promotion of clubs from the $3^{\text {rd }}$ to $2^{\text {nd }}$ tier in the men's national league significantly drives larger average attendances on State Championships - the outputs reveal that a State Federation may expect an increase of about $18 \%$ on its average attendance if one of its clubs is promoted to the Brazilian League second division. At the same time, the outputs indicate that a given State Championship might expect a rise of around 15\% 
Figure 2. Seasonal Average Matchday Revenues by State and Year.

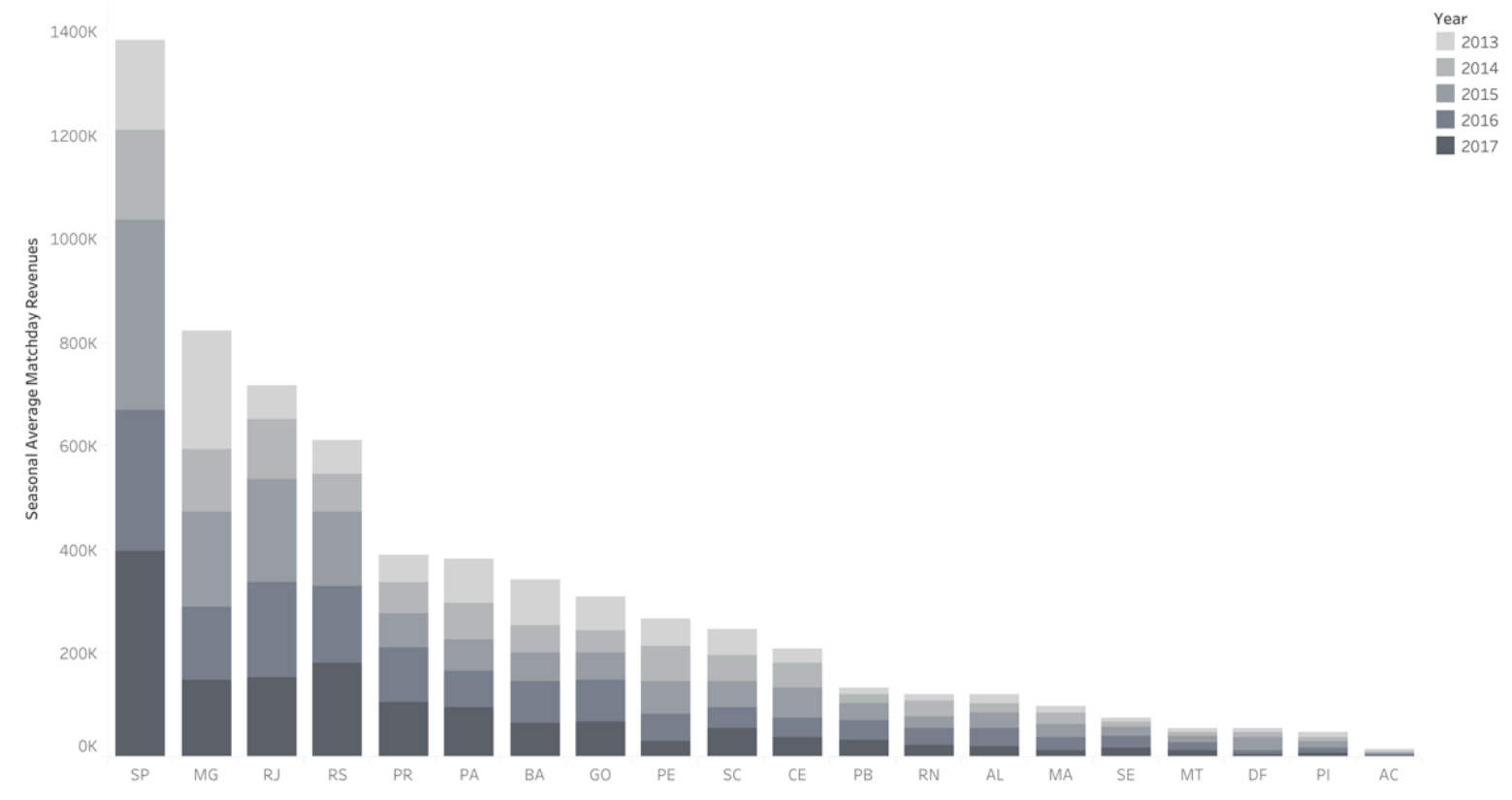

Table 2. Attendance and Revenue models.

\begin{tabular}{|c|c|c|c|c|c|}
\hline VARIABLES & $\begin{array}{r}(1) \\
a \\
\end{array}$ & $\begin{array}{r}(2) \\
r \\
\end{array}$ & $\begin{array}{r}(3) \\
\ln (a) \\
\end{array}$ & $\begin{array}{r}(4) \\
\ln (r) \\
\end{array}$ & $\begin{array}{r}(5) \\
\ln (r)^{\dagger} \\
\end{array}$ \\
\hline Promotion to $1^{\text {st }}(p l)$ & $4 \overline{448.2}$ & 18,595 & 0.135 & 0.191 & 0.191 \\
\hline & $(447.0)$ & $(15,893)$ & $(0.162)$ & $(0.172)$ & $(0.130)$ \\
\hline Promotion to $2^{\text {nd }}(p 2)$ & $\begin{array}{r}794.1 * * * \\
(284.3)\end{array}$ & $\begin{array}{r}20,920 * * \\
(10,109)\end{array}$ & $\begin{array}{c}0.179 * \\
(0.103)\end{array}$ & $\begin{array}{r}0.148 \\
(0.109)\end{array}$ & $\begin{array}{r}0.148 * \\
(0.0787)\end{array}$ \\
\hline Promotion to $3^{\text {rd }}(p 3)$ & $\begin{array}{r}316.8 \\
(332.9)\end{array}$ & $\begin{array}{r}655.2 \\
(11,837)\end{array}$ & $\begin{array}{r}0.0668 \\
(0.121)\end{array}$ & $\begin{array}{c}0.0393 \\
(0.128)\end{array}$ & $\begin{array}{l}0.0393 \\
(0.125)\end{array}$ \\
\hline Relegation to $2^{\text {nd }}(d l)$ & -653.1 & $-38,189 * *$ & -0.191 & $-0.346^{* *}$ & $-0.346^{* *}$ \\
\hline Relegation to $3^{\text {rd }}(d 2)$ & $\begin{array}{r}(436.6) \\
-834.6^{* *} \\
(361.2)\end{array}$ & $\begin{array}{r}(15,525) \\
-31,037 * * \\
(12,843)\end{array}$ & $\begin{array}{c}(0.159) \\
-0.228^{*} \\
(0.131)\end{array}$ & $\begin{array}{r}(0.168) \\
-0.195 \\
(0.139)\end{array}$ & $\begin{array}{r}(0.145) \\
-0.195 \\
(0.139)\end{array}$ \\
\hline Relegation to $4^{\text {th }}(d 3)$ & $\begin{array}{r}-441.8 \\
(425.3)\end{array}$ & $\begin{array}{r}-15,392 \\
(15,125)\end{array}$ & $\begin{array}{r}-0.0561 \\
(0.154)\end{array}$ & $\begin{array}{r}-0.244 \\
(0.164)\end{array}$ & $\begin{array}{r}-0.244 \\
(0.174)\end{array}$ \\
\hline Control Variables & Yes & Yes & Yes & Yes & Yes \\
\hline State FE & Yes & Yes & Yes & Yes & Yes \\
\hline Season FE & Yes & Yes & Yes & Yes & Yes \\
\hline Constant & $\begin{array}{c}-29,185^{*} \\
(17,258)\end{array}$ & $\begin{array}{r}-51,005 \\
(613,662)\end{array}$ & $\begin{array}{r}-3.743 \\
(6.266)\end{array}$ & $\begin{array}{r}7.188 \\
(6.641)\end{array}$ & $\begin{array}{r}7.188 \\
(6.492)\end{array}$ \\
\hline Breusch-Pagan & 0.001 & 0.000 & 0.355 & 0.007 & N/A \\
\hline Observations & 80 & 80 & 80 & 80 & 80 \\
\hline $\mathrm{R}^{2}$ & 0.929 & 0.947 & 0.946 & 0.973 & 0.973 \\
\hline Adjusted $\mathrm{R}^{2}$ & 0.875 & .907 & 0.905 & 0.952 & 0.952 \\
\hline
\end{tabular}

Note: Standard errors in parentheses; ${ }^{\dagger}$ Robust Standard errors in parentheses; N/A = Not Appropriate. $* * * \mathrm{p}<0.01$, $* * \mathrm{p}<0.05, * \mathrm{p}<0.1$ 
on matchday revenues if one of its clubs is promoted to the domestic second tier. On the other hand, relegations suggest negative consequences for both attendance and matchday revenues, as expected. If a State Championship has a club relegated from the $2^{\text {nd }}$ domestic division to the $3^{\text {rd }}$ one, it implies a statistical reduction of $23 \%$ in the attendance figures in the subsequent State Championship. Moreover, relegation from the top domestic tier to the second one would reduce the matchday revenues in a State Championship by about $35 \%$.

In the specific case of Brazilian domestic men's football, the second division could be considered as a threshold for positive/negative outcomes related to promotion and relegation in the domestic league and their potential impacts on State Championships. It is woth mentioning that the State Federations, as competition organisers, charge a percentage of the matchday revenue from home clubs on a match basis. Then, if a State Federation aims to statistically increase both attendance rates and matchday revenues, it should put its effort into supporting any of its clubs to reach the second division of the Brazilian League because it would, indeed, statistically boost those figures. Nonetheless, the promotion to Brazil's top tier, surprisingly, does not drive higher attendances and revenues on State Championships. The coefficients are - as expected - positive, but do not show any statistical difference to the second division. Therefore, the promotion of a club to the top-tier in a domestic league may benefit solely that particular club - increasing its attendances and revenues in league matches, as highlighted by Noll (2003) and Scelles et al. (2013) - but do not imply in any statistical rise in average attendances or matchday revenues for State Championships.

Although the econometric model does not allow inferences regarding the reasons for this result, a conceivable explanation would be a potential adverse demand effect, where many fans decide not to attend minor matches (at State Championships) since the club is now playing in top domestic tiers (Brazilian League Serie $A$ and $B$ ). The spillover effect reported by Wallrafen et al. (2018) in Germany may be happening in the Brazilian football market between top tier league matches and State Championship ones.

On the other hand, from a tournament-level perspective, this result may be interpreted that general fans do not discriminate between first and second-tier clubs and the impact of such clubs on the seasonal average attendance at men's State Championships are similar. Shakina, Gasparetto and Barajas (2020) recently show evidence that brand teams - which are often playing at first and second tiers of the Brazilian league - drive most of the variation of the attendance levels at the Brazilian State Championships. Such effect is even higher than the impact of the uncertainty of outcome in that setting. Nonetheless, although a relegation from $1^{\text {st }}$ division does not significantly impact attendances levels at State Championships, the matchday revenues suffer a significant reduction. Since we are working at state-level data, rather than club-level, we cannot fully explain the reasons for this effect, but we assume that it may be explained because clubs when playing at Brazilian First Division tend to charge higher ticket prices at State Championship matches, but when relegated to the second tier, they set lower prices for tickets to keep former attendance rates.

The promotion of a club to upper tiers $\left(1^{\text {st }}\right.$ and $\left.2^{\text {nd }}\right)$ in the domestic league may produce other positive externalities in State Championships that are not studied here. The presence of such promoted club could drive not only higher attendances or matchday revenues, but also boost audience levels, attract new sponsors to the tournament - to both organizers and other participants, since they will be playing against a club with more media coverage - as well as increase the playing talent within the State Championship - the recently promoted club will naturally seek for more talented players (Szymanski, 2003), which would lead other clubs into a race for better players to keep competing (Kesenne, 2006). Due to the win-maximization aim of men's 
football clubs in Brazil, the increase of the State Championship wealth could enlarge the absolute tournament quality and, hence, the talent investment and allocation (Kesenne, 2015).

The results of this research are relevant since they provide evidence that promotion and relegation of football clubs in the domestic league may impact parallel tournaments. In a setting as the Brazilian football market, essentially structured at regional levels, the understanding of the impacts of simultaneous tournaments on each other is valuable for maximizing sports performance, attendance levels and revenues. The results presented here do not close the discussion about this topic. Club-individual characteristics can be added into the modelling as well as other simultaneous tournaments can be inspected, such as domestic cups and international competitions. Lastly, the impact of promotion and relegation on broadcast ratings is an element not included here - due to the lack of data - that would also be relevant when considering the whole picture of any domestic football market.

\section{Concluding remarks}

The present letter inspects the impacts of promotion and relegation in the Brazilian League for both attendance and revenue of clubs at parallel competitions: State Championships. The results show evidence that, in general, promotions to the second tier tend to increase attendance and revenues of State Championships as well as relegation to lower divisions impact negatively them. However, the absence of effect of promotion to the top tier, although initially unexpected, would suggest a potential adverse demand effect that can be examined further.

The main limitation of the present work is that it evaluates changes in seasonal average attendance and matchday revenues. For this reason, individual characteristics of clubs are overlooked and promotions and relegations are taken as independent facts, being alike for all clubs. Nonetheless, it does not constitute an issue due to the organizational system of Brazilian football - essentially structured by State Federations. The understanding of impacts from parallel tournaments is a relevant subject there. Moreover, the reduced number of seasons under analysis may also be considered as a limitation. Further research may expand this analysis from tournament-level to club-level perspective, inspecting how relegations and promotions impact attendances on a match-by-match basis in men's Brazilian football adopting larger samples. Additional research examining whether similar effects occur in European football at parallel tournaments as domestic cups or international competitions is also encouraged.

\section{Acknowledgements}

This paper is an output of a research project implemented as part of the Basic Research Program at the National Research University Higher School of Economics (HSE).

\section{References}

Barajas, A., \& Rodríguez, P. (2010). Spanish Football Clubs Finances: Crisis and Player Salaries. International Journal of Sport Finance, 5 (1), 52-66.

Barajas, A., Rodríguez, P. (2014). Spanish football in need of financial therapy: Cut expenses and inject capital. International Journal of Sport Finance, 9 (1), 73-90.

Beech, J., Horsman, S., \& Magraw, J. (2010). Insolvency events among English football clubs. International Journal of Sports Marketing and Sponsorship, 11 (3), 53-66. https://doi.org/10.1108/IJSMS-11-03-2010-B006.

Bond, A. J., Widdop, P., \& Parnell, D. (2020). Topological network properties of the European football loan system. European Sport Management Quarterly, 20 (5), 655-678. https://doi.org/10.1080/16184742.2019.1673460. 
Borland, J., \& Macdonald, R. (2003). Demand for Sport. Oxford Review of Economic Policy, 19 (4), 478-502. https://www.jstor.org/stable/23606855.

Buraimo, B., Simmons, R., \& Szymanski, S. (2006). English Football. Journal of Sports Economics, 7(1), 29-46. https://doi.org/10.1177/1527002505282911.

Cerqua, A. (2014). If You Get Knocked Down, How Long Before You Get Up Again? International Journal of Sport Finance, 9 (4), 284-304.

Dimitropoulos, P. E., \& Tsagkanos, A. (2012). Financial performance and corporate governance in the European football industry. International Journal of Sport Finance, 7 (4), 280-308.

Dionísio, P., Leal, C., \& Moutinho, L. (2008). Fandom affiliation and tribal behaviour: A sports marketing application. Qualitative Market Research, 11 (1). 17-39. https://doi.org/10.1108/13522750810845531.

Fernandes, T., \& Neves, S. (2014). The role of servicescape as a driver of customer value in experience-centric service organizations: The Dragon Football Stadium case. Journal of Strategic Marketing, 22 (6), 548-560. https://doi.org/10.1080/0965254X.2014.914058.

Frick, B. (2007). The football players' labour market: Empirical evidence from the major European leagues. Scottish Journal of Political Economy, 54 (3), 442-446. https://doi.org/10.1111/j.1467-9485.2007.00423.x.

Gasparetto, T., \& Barajas, A. (2020). Management in a complex scenario: World Cup, alternative stadiums and demand for tickets. Managerial and Decision Economics, 41 (6), 1071-1083.

Gasparetto, T., Barajas, A., \& Fernandez-Jardon, C. M. (2018). Brand teams and distrubution of wealth in Brazilian State Championships. Sport, Business and Management, 8 (1), 2-14. https://doi.org/10.1108/SBM-03-2017-0016.

Gasparetto, T., Barajas, A., \& Rodríguez-Guerrero, P. (2020). Socio-economic factors that affect the demand for tickets in all Brazilian League tiers. Sport in Society, 23 (2), 222-233.

Hughes, M., Hughes, P., Mellahi, K., \& Guermat, C. (2010). Short-term versus long-term impact of managers: Evidence from the football industry. British Journal of Management, 21 (2), 571-589. https://doi.org/10.1111/j.1467-8551.2009.00668.x.

Kahn, L. M. (2000). The sports business as a labour market laboratory. Journal of Economic Perspectives, 14 (3), 75-94. https://www.aeaweb.org/articles?id=10.1257/jep.14.3.75.

Kesenne, S. (2006). The Win Maximization Model Reconsidered: Flexible Talent Supply and Efficiency Wages. Journal of Sports Economics, 7 (4), 416-427.

Kessene, S. (2015). Revenue Sharing and Absolute League Quality; Talent Investment and Talent Allocation. Scottish Journal of Political Economy, 62 (1), 51-58.

Kleven, H. J., Landais, C., \& Saez, E. (2013). Taxation and International Migration of Superstars: Evidence from the European Football Market. American Economic Review, 103 (5), 1892-1924. https://www.aeaweb.org/articles?id=10.1257/aer.103.5.1892.

Madalozzo, R., \& Villar, R. B. (2009). Brazilian Football: What Brings Fans to the Game? Journal of Sports Economics, 10 (6), 639-650.

Noll, R. G. (2002). The Economics of Promotion and Relegation in Sports Leagues: The Case of English Football. Journal of Sports Economics, 3 (2), 169-203. https://doi.org/10.1177/152700250200300205.

Noll, R. G. (2003). The Organization of Sports Leagues. Oxford Review of Economic Policy, 19 (4), 530-551. https://www.jstor.org/stable/23606858.

Pyun, H., Kim, J., Schlesinger, T., \& Matto, L. (2020). Positive Externalities from Professional Football Clubs in the Metropolitan Rhine-Ruhr, Germany: Trickle-Down Effects Associated with Promotion and Relegation. Sustainability, 12, 8638. doi:10.3390/su12208638. 
Scafarto, V., \& Dimitropoulos, P. (2018). Human capital and financial performance in professional football: the role of governance mechanisms. Corporate Governance, 18 (2), 289316. https://doi.org/10.1108/CG-05-2017-0096.

Scelles, N., Durand, C., Bonnal, L., Goyeau, D., \& Andreff, W. (2013). Competitive balance versus competitive intensity before a match: is one of these two concepts more relevant in explaining attendance? The case of the French football Ligue 1 over the period 2008-2011. Applied Economics, 45 (29), 4184-4192.

Scelles, N., \& François, A. (2021). Does a country's income inequality affect its citizens' quest for equality in leisure? Evidence from European men's football. Economics and Business Letters, 10 (2), 133-139.

Scelles, N., Szymanski, S., \& Dermit-Richard, N. (2018). Insolvency in French soccer: The case of payment failure. Journal of Sports Economics, 19 (5), 603-624. https://doi.org/10.1177/1527002516674510.

Scholl, H. J., \& Carlson, T. S. (2012). Professional sports teams on the Web: A comparative study employing the information management perspective. European Sport Management Quarterly, 12 (2), 137-160. https://doi.org/10.1080/16184742.2012.670254.

Shakina, E., Gasparetto, T., \& Barajas, A. (2020). Football Fans' Emotions: Uncertainty Against Brand Perception. Frontiers in Psychology, 11, 659, 1-9. Doi: 10.3389/fpsyg.2020.00659.

Solberg, H. A., \& Haugen, K. K. (2010). European club football: why enormous revenues are not enough? Sport in Society, 13 (2), 329-343. https://doi.org/10.1080/17430430903523036.

Szymanski, S. (2003). The Economic Design of Sporting Contests. Journal of Economic Literature, 41 (4), 1137-1187. https://www.jstor.org/stable/3217458.

Szymanski, S. (2017). Entry into exit: insolvency in English professional football. Scottish Journal of Political Economy, 64 (4), 419-444.

Szymanski, S., \& Smith, R. (1997). The English Football Industry: profit, performance and industrial structure. International Review of Applied Economics, 11 (1), 135-153. https://doi.org/10.1080/02692179700000008.

Szymanski, S., \& Weimar, D. (2019). Insolvencies in Professional Football: A German Sonderweg? International Journal of Sport Finance, 14 (1), 54-68.

Trequattrini, R., Massaro, M., Lardo, A., \& Cuozzo, B. (2019). Knowledge transfer and managers turnover: impact on team performance. Business Process Management Journal, 25 (1), 69-83. https://doi.org/10.1108/BPMJ-06-2017-0169.

Zimbalist, A. (2003). Sport as business. Oxford Review of Economic Policy, 19 (4), 503-511. https://doi.org/10.1093/oxrep/19.4.503. 